УДК 634.034

doi: 10.36359/scivp.2019-20-2.05

\title{
ВПЛИВ ШИШОК ХМЕЛЮ І ВІТАМІНУ Е НА РУБЦЕВУ ФЕРМЕНТАЦЮ У КОРІВ ПІСЛЯ ОТЕЛЕННЯ
}

\author{
I. В. Вудмаска, д-р с.-г. наук, \\ C. Р. Сачко, аспірант, \\ В. Ю. Гудима, канд. с.-г. наук, \\ Н. В. Голова, канд. с.-г. наук, \\ Н. І. Пахолків, канд. вет. наук \\ Інститут біології тварин НААН, \\ вул. В. Стуса, 38, м. Львів, 79034, Україна
}

У досліді використано 2 групи сухостійних корів украӥнськой молочной чорно-рябої породи з продуктивністю за попередню лактацію 6-7 тис. кг молока, по 10 тварин у групі. Тварини отримували стандартний збалансований раціон. Перша група - контрольна. До раціону корів другої групи додавали 300 мг а-токоферолу ацетату (0,6 г Ровімікс E-50) та 1 г/кг сухих шишок хмелю на кг сухої речовини корму протягом останніх 3-х тижнів сухостою та перших трьох тижнів після отелення. Введення до рачіону корів шишок хмелю та вітаміну E вплинуло на перебіг рубиевої ферментащії. Зокрема, досліджувана кормова добавка стимулювала целюлозолітичну та пригнічувала протеолітичну активність $(p<0,01)$. Унаслідок вищої целюлозолітичної активності у вмісті зростала концентрація летких жирних кислот. Зниження протеолітичної активності призвело до зменшення концентрачії аміаку в рубиі (р<0,05). При иььму кількість мікробного азоту у вмісті рубия корів дослідної групи помірно зросла, щзо вказує на відсутність негативної дії добавки на мікрофлору в иілому. Добовий надій корів дослідної групи збільшився на 4,5\% порівняно до надою корів контрольної групи. Внаслідок дещз вищої жирності молока, надій на базисну жирність зріс на 6,4\%.

Ключові слова: КОРОВИ, ВМІСТ РУБЦЯ, ШИШКИ ХМЕЛЮ, ВІТАМІН Е.

Найпоширеніші на даний час іонофорні антибіотики: монензин, лазалоцид, саліноміцин, наразин, які продукуються бактеріями роду Streptomyces. Механізм їх дії полягає у перенесенні іонів натрію, калію, кальцію, магнію через клітинні мембрани грампозитивних бактерій і протистів, внаслідок чого порушується баланс цих іонів у клітині [1]. Іонофори широко застосовуються у птахівництві як кокцидіостатики, а у США i Канаді - для стимулювання приростів відгодівельної худоби $[1,2]$. Такий ефект на продуктивність жуйних тварин зумовлений ігібуванням іонофорами активності аміакоутворюючих i, меншою мірою, целюлозолітичних бактерій рубця, тобто вони зменшують утворення аміаку i ацетату i збільшують утворення пропіонату в рубці [3]. У Європейському Союзі з 2006 року заборонене використання антибіотиків-стимуляторів росту, в тому числі й іонофорів [4], їх застосовують лише для лікування тварин. В Україні кормові антибіотики будуть заборонені з 19 січня 2020 року, проте кокцидіостатики (до яких належать іонофори) під цю заборону не підпадають [5].

У високопродуктивних корів у перед- та післяродовий період часто спостерігається надмірне аміакоутворення в рубці, що є одним 3 чинників порушення функції печінки 3 наступним жировим іï переродженням та захворюванням на кетоз. Використання іонофорних антибіотиків дозволяє покращити стан тварин [6-8].

Супліддя (шишки) хмелю містять ряд компонентів: поліфеноли, ефірні олії, смоли, які володіють значною біологічною активністю і виявляють протимікробну, антиоксидантну, протизапальну, антиканцерогенну, естрогенну дію $[9,10]$. Найбільш виражена протимікробна 
активність характерна для поліфенольних сполук хмелю: хумулону і лупулону (інша назва $\alpha$ i $\beta$-кислоти) та їх похідних [11]. Ці сполуки вибірково пригнічують життєдіяльність грампозитивних бактерій, впливаючи на транспорт іонів через бактеріальну мембрану за механізмами подібними до дії антибіотиків-іонофорів [7, 12], тому їх часто називають фітоіонофорами.

Важливим недоліком застосування іонофорних антибіотиків для корів є те, що окрім корисного для продуктивності тварин пригнічення протеолітичної активності рубцевої мікрофлори, одночасно пригнічується активність целюлозолітичних бактерій, що призводить до зменшення продукції ацетату i, як наслідок, зниження жирності молока [3]. Тобто, якщо при вирощуванні ВРХ на м'ясо зниження ацетат-пропіонатного співвідношення у рубці сприяє більшим приростам, у молочних корів така зміна призводить до негативного впливу на молочну продуктивність $[6,7]$.

Останніми роками встановлено регуляторну дію збільшення вмісту вітаміну Е в раціоні жуйних на активність бактерій рубця, зокрема виявлено стимулюючий вплив $\alpha$-токоферолу на рубцеву ферментацію $[13,14]$. Виходячи з цього, метою наших досліджень було встановлення спільної дії введення до складу раціону корів у перед- та післяродовий період шишок хмелю та вітаміну Е на ферментацію у рубці.

Матеріали і методи. Використано 2 групи корів української молочної чорно-рябої породи 3 продуктивністю за попередню лактацію 6-7 тис. кг молока, по 10 тварин у групі. Тварини отримували стандартний збалансований раціон, який містив: сінаж різнотравний, силос кукурудзяний, ячмінно-кукурудзяну дерть, шрот соєвий, мелясу, сіль кормову, мінерально-вітамінний премікс. Перша група була контролем. Коровам другої групи додавали по 300 мг $\alpha$-токоферолу ацетату (0,6 г Ровімікс E-50) та 1 г/кг сухих шишок хмелю на кг сухої речовини раціону. Кормову добавку згодовували протягом останніх 3 -х тижнів сухостою та перших 3-х тижнів після отелення. Вміст рубця брали одноразово через тиждень після отелення, молоко - через місяць після отелення. У рубцевій рідині визначали целюлозолітичну, амілолітичну, протеолітичну та ліполітичну активності, концентрацію білкового та мікробного азоту методом К'єльдаля, вміст аміаку за Конвеєм, молочної кислоти за Баркером-Саммерсоном, летких жирних кислот, показник $\mathrm{pH}$, згідно методів викладених у довіднику «Лабораторні методи досліджень у біології, тваринництві та ветеринарній медицині» [15]. У молоці визначали вміст білка, жиру, лактози на аналізаторі "Екомілк". Отримані результати опрацьовували статистично з використанням програми Excel.

Результати й обговорення. Згідно 3 даними, показаними у таблиці 1 , введення до раціону корів шишок хмелю пригнічувало протеолітичну активність вмісту рубця $(\mathrm{p}<0,01)$. Це закономірно, оскільки поліфеноли суплідь хмелю володіють протимікробними властивостями подібними до антибіотиків-іонофорів, тобто вони пригнічують життєдіяльність грампозитивних бактерій.

Таблиия 1

Ензиматична активність вмісту рубця $(\mathrm{M} \pm \mathrm{m}, \mathrm{n}=\mathbf{5})$

\begin{tabular}{|l|c|c|}
\hline \multicolumn{1}{|c|}{ Показники } & \multicolumn{2}{|c|}{ Групи тварин } \\
\cline { 2 - 3 } & Контроль & Хміль+вітамін Е \\
\hline Амілолітична, тис. ум. ам. од. & $422,68 \pm 9,75$ & $434,37 \pm 14,04$ \\
\hline Целюлозолітична, \% актив. & $35,23 \pm 1,75$ & $5,15 \pm 0,29 * *$ \\
\hline Протеолітична, екв. тис/100мл/хв. & $7,0 \pm 0,34$ & $5,99 \pm 0,40$ \\
\hline Ліполітична, ммоль НЕЖК & $6,23 \pm 0,31$ & 58 \\
\hline
\end{tabular}

Найвищою протеолітичною активністю у рубці володіє група грам-позитивних бактерій - так звані гіперпродуценти аміаку (hyper-ammonia producing bacteria, HAP). Важливо, що при цьому не знизилась целюлозолітична активність. Целюлозолітичні бактерії, переважно, грам-позитивні і, відповідно, вони також чутливі до дії іонофорів. Разом 3 тим, високі дози вітаміну Е стимулюють діяльність целюлозолітичних бактерій. Завдяки цьому 
одночасне додавання до раціону корів шишок хмелю і вітаміну Е взаємно компенсувало їх вплив на целюлозолітичну активність вмісту рубця. Амілолітичні та ліполітичні бактерії рубця жуйний переважно грам-негативні, тому впливу на їх активність не спостерігалось.

Зміна протеолітичної активності вплинула на показники азотового обміну в рубці (табл. 2). Зокрема, концентрація білкового азоту зросла на $22 \%(\mathrm{p}<0,05)$, тоді як кількість мікробного азоту залишилась без змін. При цьому, у вмісті рубця корів, що отримували кормову добавку знизилась концентрація аміаку $(\mathrm{p}<0,01)$. Це свідчить про зменшення розщеплення протеїну корму при збереженні загальної чисельності мікробної маси. Відомо, що компоненти суплідь хмелю виявляють бактерицидну дію до грампозитивних бактерій. Найвища їх активність спостерігається щодо нечисельної але метаболічно дуже активної групи бактерій - гіперпродуцентів аміаку, що й є причиною зростання кількості білкового азоту і зниження концентрації аміачного азоту у рубці корів дослідної групи.

Відхилень у показниках вуглеводного обміну не виявлено. Концентрація лактату у вмісті рубця корів обох груп не відрізнялась, а сумарна концентрація летких жирних кислот дещо зростала, проте ця зміна була кількісно незначною і статистично не вірогідною.

Азотово-вуглеводний обмін у вмісті рубця $(\mathrm{M} \pm \mathrm{m}, \mathrm{n}=5)$

Таблиия 2

\begin{tabular}{|l|c|c|}
\hline \multirow{2}{*}{ Показники } & \multicolumn{2}{|c|}{ Групи тварин } \\
\cline { 2 - 3 } & Контроль & Хміль+вітамін Е \\
\hline Білковий азот, ммоль/л & $51,48 \pm 2,61$ & $62,80 \pm 3,59^{*}$ \\
\hline Мікробний азот, ммоль/л & $37,15 \pm 2,45$ & $40,94 \pm 3,19$ \\
\hline ЛЖК, ммоль/л & $119,85 \pm 5,11$ & $128,45 \pm 5,35$ \\
\hline Азот аміаку, ммоль/л & $6,99 \pm 0,13$ & $5,35 \pm 0,54 * *$ \\
\hline Лактат, ммоль/л & $4,22 \pm 0,09$ & $6,18 \pm 0,12$ \\
\hline рН & $6,93 \pm 0,14$ & $6,85 \pm 0,19$ \\
\hline
\end{tabular}

Використання кормової добавки помірно збільшило вміст жиру та протеїну у молоці корів дослідної групи. Слід зазначити, що іонофори та вітамін Е по-різному впливають на жирність молока. Згідно наших попередніх досліджень та літературних даних монензин супліддя хмелю знижують вміст жиру в молоці, а вітамін Е - навпаки, підвищує його. У цьому досліді, за сумісного використання шишок хмелю і вітаміну Е жирність молока була дещо більшою ніж у контролі, отже вітамін Е компенсував жиродепресуючу дію іонофорів хмелю.

Добовий надій корів дослідної групи збільшився на 4,5%, порівняно до надою корів контрольної групи. Внаслідок дещо вищої жирності молока, надій на базисну жирність зріс на 6,4 \%. Наявна тенденція до збільшення виходу молочного жиру та протеїну.

Разом $з$ тим, зміни молочної продуктивності статистично не вірогідні, що пояснюється недостатньою для оцінки такого параметру кількістю експериментальних тварин. Тим не менше, метою наших досліджень було не стимулювання надоїв, а покращення метаболічного стану корів після отелення, а саме - попередження надмірного кетогенезу та оксидативного стресу.

\section{В И С Н О В К И}

Додавання до корму корів комплексної добавки що містить 300 мг $\alpha$-токоферолу ацетату та 1 г/кг на кг сухої речовини раціону сухих шишок хмелю пригнічує протеолітичну активність та зменшує концентрацію аміаку у рубці, що важливо для нормалізації рубцевої ферментації та попередження інтоксикації аміаком у перші тижні після отелення. Комплексне використання вітаміну Е та шишок хмелю попереджує негативний вплив іонофорних сполук хмелю на целюлозолітичні бактерії. 
Перспективи досліджень. Зміна інтенсивності і спрямованості рубцевої ферментації впливає на перебіг метаболічних процесів в організмі жуйних тварин. Вітамін Е та біологічно активні компоненти хмелю володіють антиоксидантними властивостями. Виходячи з цього, важливо встановити вплив досліджуваної кормової добавки на функцію печінки та загальний метаболічний профіль корів. Необхідно вивчити дію шишок хмелю у комплексі з іншими регуляторами рубцевої ферментації та гепатопротекторними препаратами.

\title{
INFLUENCE OF HOP CONES AND VITAMIN E SUPPLEMENTATION ON RUMEN FERMENTATION IN TRANSITION DAIRY COWS
}

\author{
I. V. Vudmaska, S. R. Sachko, V. Yu. Hudyma, N. V. Golova, N. I. Pakholkiv \\ Institute of Animal Biology of NAAS, \\ 38 V. Stusa st., Lviv, 79034, Ukraine
}

\section{S U M M A R Y}

After calving cows get into negative energy balance accompanied by glucose deficiency and excessive release of fatty acids from adipose tissue. In assessing the metabolic status of cows during this period, the focus is on the violation of carbohydrate and lipid metabolism, but such important aspect as the ammonia intoxication, what is one of the factors of liver degeneration remains often out of attention. The main contribution to the formation of ammonia in the rumen is performed by grampositive hyper ammonia producing bacteria (HAB). The activities of these bacteria are inhibited by ionophore antibiotics that are prohibited for use as a feed supplement in the EU. The substitute for antibiotics may be hop cones contained substances that selectively affect gram-positive bacteria, including HAB. However, ionophores inhibit cellulolytic bacteria activity too. High doses of dietary vitamin $\mathrm{E}$ can stimulate fiber degradation in the rumen. The purpose of our study was the possibility of use hops cones and vitamin $\mathrm{E}$ as a complex for prevention of metabolic disorders in the transition cows.

The experiment used twenty Ukrainian dairy black-and-white breed cows; milk yield 6000$7000 \mathrm{~kg}$ for previous lactation; divided into two groups 10 animals each. The first group is control. Diet of the second group was supplemented with (per kg DM) $1 \mathrm{~g}$ of dry hop cones and $300 \mathrm{mg}$ of $\alpha$ tocopherol acetate as a $0.6 \mathrm{~g}$ of Rovimix E-50 (NRC 2001 recommends $80 \mathrm{mg} / \mathrm{kg}$ for dry cows and $30 \mathrm{mg} / \mathrm{kg}$ for lactating cows). Experiment lasted during transition period (from $3 \mathrm{wk}$ prepartum until 3 wk postpartum).

Supplementation the diet with hop cones and vitamin $\mathrm{E}$ has affected rumen fermentation. In particular, the feed additive stimulated cellulosolytic and suppressed proteolytic activities $(\mathrm{p}<0.01)$. Reduced proteolytic activity led to a decrease in ammonia concentration in the rumen $(\mathrm{p}<0.05)$. At the same time, the amount of microbial nitrogen in the rumen of the experimental group of cows has moderately increased, what indicates the absence of depress effect of the additive on the rumen microbiota in general. Differences in carbohydrate indices were not found. The concentration of lactate in rumen fluid of the cows of both groups did not differ, the total concentration of volatile fatty acids increased somewhat, however, this changes was quantitatively and statistically insignificant. Daily milk yield of the experimental group cows elevated by $4.5 \%$ compared to the control group. Due to higher milk fat content, fat corrected milk yield was higher by $6.4 \%$.

Keywords. TRANSITION COWS, RUMEN, HOP CONES, VITAMIN E. 


\title{
ВЛИЯНИЕ ШИШЕК ХМЕЛЯ И ВИТАМИНА Е НА ФЕРМЕНТАЦИЮ В РУБЦЕ КОРОВ ПОСЛЕ ОТЕЛА
}

\author{
И. В. Вудмаска, С. Р. Сачко, В. Ю. Гудыма, Н. В. Голова, Н. И. Пахолкив \\ Институт биологии животных НААН, \\ ул. В. Стуса, 38, г. Львов, 79034, Украина
}

\section{А Н Н О Т А ЦИ Я}

В опыте использовано 2 группы сухостойных коров украинской молочной чернопестрой породы с молочной продуктивностью 6-7 тыс. кг за предыдущею лактацию, по 10 животных в группе. Животные получали стандартный сбалансированный рацион. Первая группа - контрольная. В рацион коров второй группы добавляли 300 мг $\alpha$-токоферола ацетата $(0,6$ г Ровимикс Е-50) и 1 г / кг сухих шишек хмеля на кг сухого вещества корма в течение последних 3-х недель сухостоя и первых 3-х недель после отела. Введение в рацион коров шишек хмеля и витамина Е влияло на ход рубцовой ферментации. В частности, исследуемая кормовая добавка стимулировала целлюлозолитическую и угнетала протеолитическую активность ( $\mathrm{p}<0,01)$. Вследствие более высокой целлюлозолитической активности в содержании рубца возросла концентрация летучих жирных кислот. Снижение протеолитической активности вызвало уменьшение концентрации аммиака в рубце $(\mathrm{p}<0,05)$. При этом количество микробного азота в содержимом рубца коров опытной группы несколько возросла, что указывает на отсутствие отрицательного действия добавки на микрофлору в целом. Суточный удой коров опытной группы увеличился на 4,5\% по сравнению с удоем коров контрольной группы. Вследствие несколько большей жирности молока, удой на базисную жирность увеличился на 6,4 \%. ВИТАМИН Е.

Ключевые слова: КОРОВЫ, СОДЕРЖИМОЕ РУБЦА, ШИШКИ ХМЕЛЯ,

\section{References}

1. Hersom M., Thrift T. Application of ionophores in cattle diets. UF/IFAS Extension: https://edis.ifas.ufl.edu/an285.

2. Abrar A, Tsukahara T, Kondo M, Ban-Tokuda T, Chao W, Matsui H. Effect of monensin withdrawal on rumen fermentation, methanogenesis and microbial populations in cattle. Animal Science Journal, 2015, Vol. 86, no. 9, pp. 849-54. DOI:10.1111/asj.12368.

3. Vudmaska I., Petruk A., Vaskiv R., Vlizlo V. Comparison of monensin and hop cones effects on rumen fermentation and blood parameters in transition dairy cows. Hungarian Veterinary Journal, 2018. Vol. 140, no. 1, pp.299-304.

4. Regulation (EC) No $1831 / 2003$ of the European Parliament and the Council of 22 September 2003 on Additives for Use in Animal Nutrition. L268/236. OJEU, 2003.

5. Zakon Ukrayiny № 2264-VIII «Pro bezpechnist ta gigiyenu kormiv» (Vidomosti Verxovnoyi Rady (VVR), 2018, № 10, st.53. (in Ukrainian).

6. Duffield TF, Bagg RN. Use of ionophores in lactating dairy cattle: a review. The Canadian Veterinary Journal, 2000, Vol. 41, no. 5, pp. 388-94.

7. Mullins C. R., Mamedova L. K., Brouk M. J., Moore C. E., Green H. B., Perfield K. L., Smith J. F., Harner J. P., Bradford B. J. Effects of monensin on metabolic parameters, feeding behavior, and productivity of transition dairy cows. Journal of Dairy Science, 2012, Vol. 95, pp. 1323-1336. DOI: 10.3168/jds.2011-4744. 
8. Weiskirchen R., Mahli A., Weiskirchen S., Hellerbrand C. The hop constituent xanthohumol exhibits hepatoprotective effects and inhibits the activation of hepatic stellate cells at different levels. Frontiers in veterinary science, 2015, 6, P. 140. DOI: 10.3389/fphys.2015.00140.

9. Karabín M, Hudcová T, Jelínek L, Dostálek P. Biologically active compounds from hops and prospects for their use. Comprehensive Reviews in Food Science and Food Safety. Vol.15, 2016, pp. 542-567. DOI.org/10.1111/1541-4337.12201.

10. Hop acids as a replacement for antibiotics in animal feed. Patent № US 8197863 B2. Date of Patent: 12. 06. 2012.

11. Flythe M. D. Flythe M. D., Kagan I. A., Wang Y., Narvaez N. Hops (Humulus lupulus L.) Bitter acids: modulation of rumen fermentation and potential as an alternative growth promoter. Frontiers in veterinary science, 2017, Vol. 4, 131. Published online 2017 Aug 21. DOI: 10.3389/fvets.2017.00131.

12. Narvaez N., Wang Y., Xu Z., McAllister T. Effects of hops on in vitro ruminal fermentation of diets varying in forage content. Livestock Science, 2011, Vol. 138, no.1-3, pp. 193201. DOI.org/10.1016/j.livsci.2010.12.028.

13. Pottier J. Effect of dietary vitamin E on rumen biohydrogenation pathways and milk fat depression in dairy cows fed high-fat diets. Journal of Dairy Science, 2006, Vol. 89, pp. 685-692. DOI: 10.3168/jds.S0022-0302(06)72131-2.

14. Wei $\mathrm{C}$, Lin $\mathrm{S}$, Wu J, Zhao G, Zhang T, Zheng W. supplementing vitamin $\mathrm{E}$ to the ration of beef cattle increased the utilization efficiency of dietary nitrogen. Asian-Australasian Journal of Animal Sciences, 2016, Vol. 9, no. 3, 32-377. DOI: 10.5713/ajas.15.0322.

15. Vlizlo V. V., Fedoruk R. S., Ratych I. B. et al. Laboratory methods of investigation in biology, stock-breeding and veterinary : Reference book ; Edited by V. V. Vlizlo. Lviv : SPOLOM, 2012, 764 p. (in Ukrainian).

Рецензент - Д. Д. Остапів, д. с.-г. н., с. н. с., Інститут біології тварин НААН. 